\title{
THE EFFECT OF Cinnamomum burmannii WATER EXTRACTION AGAINST Staphylococcus aureus, Enterobacter spp., Pseudomonas aeruginosa, AND Candida albicans: IN VITRO STUDY
}

\author{
Bernadette Dian Novita ${ }^{1}$, Silvia Sutandhio ${ }^{2}$ \\ ${ }^{1}$ Department of Pharmacology and Therapy, ${ }^{2}$ Department of Microbiology, Faculty of Medicine, Widya Mandala \\ Catholic University, Surabaya, Indonesia
}

\section{ABSTRACT}

\begin{abstract}
Indonesian cinnamon (Cinnamomum burmannii) is a native plant of Indonesia that has a lot of potential. The most consumed part is the bark. This study aims to examine the antimicrobial effect of Cinnamomum burmannii bark extract on various types of pathogenic microbes, namely Staphylococcus aureus, Enterobacter spp., Pseudomonas aeruginosa, and Candida albicans. An experimental study using a water extract (infusion) of Cinnamomum burmannii bark and a microbial test obtained from the Faculty of Pharmacy, Widya Mandala Catholic University, Surabaya. The antimicrobial effect test was carried out by the microdilution method in 96 -wellmicroplate to determine the Minimum Inhibitory Level (MIC) and implantation on solid media to determine the Minimum Kill Rate (KBM). The MIC and KBM against Staphylococcus aureus were 625-1,250 ppm and 1,250-2,500 ppm, respectively. MIC and KBM for Enterobacter spp., Pseudomonas aeruginosa, and Candida albicans were not found at the highest concentrations tested at 10,000 ppm. Cinnamomum burmannii extract can be used as a potential ingredient with antimicrobial effects, especially against Grampositive bacteria. Future studies should pay attention to the quality of simplicia, particle size, and the most effective extraction methods extracting antimicrobial substances from simplicia.
\end{abstract}

Keywords: Antibacterial activity; water extraction of Cinnamomum burmannii; Staphylococcus aureus; Pseudomonas aeruginosa; Enterobacter spp.; Candida albicans

\section{ABSTRAK}

Kayu manis Indonesia (Cinnamomum burmannii) adalah tanaman asli Indonesia yang memiliki banyak potensi. Bagian yang paling banyak dikonsumsi adalah kulit kayunya. Penelitian ini bertujuan untuk menguji efek antimikroba ekstrak kulit kayu Cinnamomum burmannii terhadap berbagai jenis mikroba patogen, yaitu Staphylococcus aureus, Enterobacter spp., Pseudomonas aeruginosa, dan Candida albicans. Penelitian eksperimental menggunakan ekstrak air (infus) kulit kayu Cinnamomum burmannii dan mikroba uji yang didapat dari Fakultas Farmasi Universitas Katolik Widya Mandala Surabaya. Uji efek antimikroba dilakukan dengan metode mikrodilusi dalam 96-well-microplate untuk menentukan Kadar Hambat Minimum (KHM) dan penanaman pada media padat untuk menentukan Kadar Bunuh Minimum (KBM). KHM dan KBM terhadap Staphylococcus aureus berturut-turut adalah 625-1.250 ppm dan 1.250-2.500 ppm. KHM dan KBM untuk Enterobacter spp., Pseudomonas aeruginosa, dan Candida albicans tidak didapatkan pada konsentrasi tertinggi yang diuji yaitu 10.000 ppm. Ekstrak Cinnamomum burmannii dapat dijadikan salah satu bahan potensial dengan efek antimikroba, khususnya terhadap bakteri Gram positif. Penelitian selanjutnya hendaknya memperhatikan mutu simplisia, ukuran partikel, dan cara ekstraksi yang paling efektif menyarikan zat antimikroba dari simplisia.

Kata kunci: Aktivitas antibakteri; ekstraksi air Cinnamomum burmannii; Staphylococcus aureus; Pseudomonas aeruginosa; Enterobacter spp.; Candida albicans

Correspondence: Bernadette Dian Novita, Department of Pharmacology and Therapy, Faculty of Medicine, Widya Mandala Catholic University, Surabaya, Indonesia. E-mail: novita@ukwms.ac.id

pISSN:2355-8393 • eISSN: 2599-056x • doi: http://dx.doi.org/10.20473/fmi.v55i4.17325

- Fol Med Indones. 2019;55:285-289 • Received 22 Nov $2018 \bullet$ Accepted 16 May 2019

- Open access under CC-BY-NC-SA license • Available at https://e-journal.unair.ac.id/FMI/

\section{INTRODUCTION}

Nowadays, the world faces the problem of microbial resistance to antibiotics. Therefore, this situation encourages experts to find safe and effective antimicrobial ingredients, especially from herbs (Vangalapati et al 2012, Ferry 2013). The Infectious
Diseases Society of America adds Staphylococcus aureus (S. aureus), Klebsiella spp., Enterobacter spp., and Pseudomonas aeruginosa ( $P$. aeruginosa) into mnemonic ESKAPE group (Enterococcus faecium, $S$. aureus, Klebsiella pneumoniae, Acinetobacter baumannii, $P$ aeruginosa, and Enterobacter spp.), a group of bacteria that develop resistance to 
antimicrobial agents, and cause serious health problems related to pathogenesis and transmission (Aubert, Flannagan \& Valvano 2008, Forsythe et al 2015). Candida spp. is one of the microbes reported to be the most common cause of nosocomial infections in the United States in 2009-2010 and Europe in the year 2010-2011. Among other Candida species, Candida albicans ( $C$. albicans) is the species that most often causes health problems (Groisman 2001, Peterson 2017). Due to these medical interests, the four microbes were used in this study.

Cinnamomum burmannii (C. burmannii), is an Indonesian native plant that has long been used as a cooking spice, natural preservative, cosmetics and traditional medicine. All parts of the cinnamon such bark, branches, twigs and leaves, contain useful phytochemicals (Nabavi et al 2015). However, the bark's part is widely and commonly used. Several studies on $C$. burmannii concluded that essential oils and extracts from the bark (cortex) of $C$. burmannii has antimicrobial effects (Ulbricht et al 2015, Zhang et al 2015). Cinnamon extract has an effect on the growth of Staphylococcus mutans which is carriogenic bacteria (Waty et al 2018).

This study aim was to examine the antibacterial activity of $C$. burmanii water extraction against Staphylococcus aureus, Pseudomonas aeruginosa, Enterobacter spp, and Candida albicans in various IC50 value in a range of 625 to $10.000 \mu \mathrm{g} / \mathrm{mL}$.

\section{MATERIALS AND METHODS}

\section{Water extraction}

Cinnamomum burmannii (C. burmannii) was extracted by using $(\mathrm{H} 2 \mathrm{O})$ water extraction methods. 10 grams of crushed $C$. burmannii bark was extrated in $100 \mathrm{~mL}$ of distilled water infusion at $90^{\circ} \mathrm{C}$ for 20 minutes. The results obtained are freeze-dry to evaporate the water content(Ervina, Nawu and Esar 2016).

The Minimum Inhibition Concentration is the lowest concentration of $C$. burmannii water extraction inhibits microbial growth. It was seen in the results of micro delusion culture on Mueller Hinton Broth (MHB) and Sabouraud-Dextrose Broth (SDB) with absorbance 90\% approach negative control (Nester et al 2013, Public Health England 2014). The Minimum Bactericidal Concentration (MBC) is the minimum concentration of C. burmannii $\mathrm{H} 2 \mathrm{O}$ extract that has ability to kill microbes. It was shown in Mueller Hinton Agar (MHA) and Sabouraud-Dextrose Agar (SDA) culture with a reduction of $99.9 \%$ of the amount inoculated bacteria
(Nester et al 2013, Public Health England 2014). Muller-Hinton Broth (MHB) were used in antibacterial assay for culturing the bacteria while for antifungal assay, Sabouraud-Dextrose Agar (SDA) and SabouraudDextrose Broth (SDB) were used, and both of the agar plates and broth were stored at $4{ }^{\circ} \mathrm{C}$ (Fadhlina et al 2013). The test microbes used for this study were Staphylococcus aureus (S. aureus), Enterobacter spp., Pseudomonas aeruginosa ( $P$. aeruginosa), and Candida albicans (C. albicans). All microbial species are stored isolates obtained from the laboratory of the Faculty of Pharmacy, Widya Mandala Catholic University, Surabaya.

\section{Preparation of inoculums}

Stock culture for each of the tested microorganisms was sub-cultured to obtain single colonies. Three wellisolated colonies of the same morphological type were selected from an agar plate culture. The top of each colony was touched with a loop and transferred into a falcon tube containing $10 \mathrm{~mL}$ of $\mathrm{MHB}$ and SDB for bacteria and fungi. Both bacteria and fungi were incubated at $37{ }^{\circ} \mathrm{C}$ for 24 hours. The optical densities (OD) of the incubated bacterial and fungal inoculums were measured using spectrophotometry. The bacteria and fungus turbidity were measured at $595 \mathrm{~nm}$ (Fadhlina et al 2013, Ervina et al 2016, Waty et al 2018).

\section{Minimum Inhibitory Concentration (MIC) Assay}

The MIC of $C$. burmanii water extraction was determined by the broth micro-dilution method. A 96well plate was used for this assay whereby each of the wells plate was loaded with the inoculums grown to an exponential phase containing 107 and $104 \mathrm{CFU} / \mathrm{mL}$ of bacteria and fungi. $10.000 \mu \mathrm{g} / \mathrm{mL}$ of $C$. burmanii water extraction was the highest concentration in this study. It transferred into the inoculated well $(270 \mu \mathrm{L})$. Two-fold serial dilution was performed by transferring $100 \mu \mathrm{L}$ from the highest concentration of treated culture into the next well so that the final volume of each well was 200 $\mu \mathrm{L}$. Finally, all of the tested plates were incubated. The standard antibiotics were tested in the same manner as the stated steps, and done in five repetitions.

\section{Minimum Bactericidal Concentration (MBC) and Minimum Fungicidal Concentration}

(MFC) assay is treated cultures containing concentrations equal to and higher than the MIC value were swabbed onto the agar plate. The concentration that gave zero subculture growth on the agar after the incubation was considered as MBC. MFC for selected fungi applied the same procedures as MBC. 


\section{RESULTS}

The microplate was filled with $156,25-10.000 \mu \mathrm{g} / \mathrm{mL}$ of C. burmanii water extraction (5 repetitions) and $S$. aureus suspension. As control, the other part of microplate was also filled with $0.375-1,5 \mu \mathrm{g} / \mathrm{mL}$ of penicillin and $S$. aureus suspension, and also sterile broth and $0.9 \% \mathrm{NaCl}$. The microplate was incubated in $370 \mathrm{C}$ for 24 hours. Using a microplate reader for OD, the absorbance was read in a wavelength of $595 \mathrm{~nm}$. The MIC of $C$. burmanii water extraction against Staphylococcus aureus was found at the concentration of $625-1.250 \mu \mathrm{g} / \mathrm{mL}$ (Table 1). Moreover, the MBC was at the concentration of 1,250-2.500 $\mu \mathrm{g} / \mathrm{mL}$ (Fig. 1).

However, $C$. burmannii water extract in the concentration of 156,25 to $10.000 \mu \mathrm{g} / \mathrm{mL}$ had no antibacterial effect against Pseudomonas aeruginosa, and Enterobacter spp, and nor antifungal against Candida albicans (Table 1).

Table 1. Minimum-Inhibitory Concentrations $(\mu \mathrm{g} / \mathrm{mL})$ and Minimum-Bactericidal Concentrations $(\mu \mathrm{g} / \mathrm{mL})$ of Cinnamomum burmanii water extraction

\begin{tabular}{lcc}
\hline \multicolumn{1}{c}{ Bacteria/Fungi } & MIC & MBC \\
\hline Staphylococcus aureus & 625 & 1250 \\
Pseudomonas aeruginosa & - & - \\
Enterobacter spp & - & - \\
Candida albicans & - & - \\
\hline
\end{tabular}

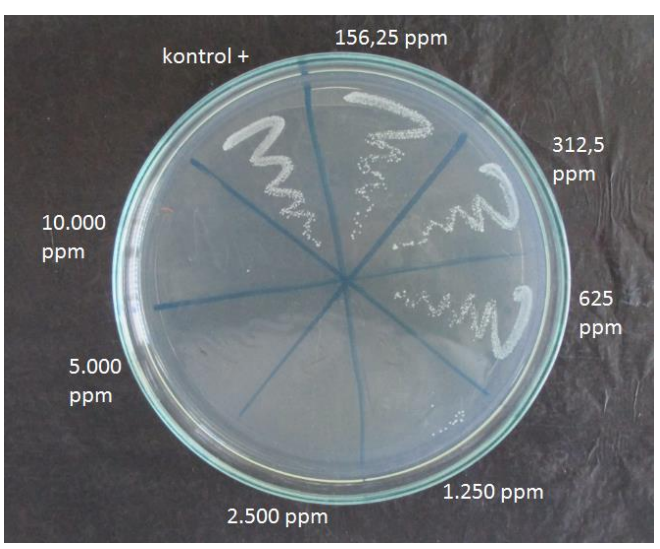

Fig. 1. Minimum-Bactericidal Concentrations $(\mu \mathrm{g} / \mathrm{mL})$ of Cinnamomum burmanii water extraction for Staphyloccus aureus.

\section{DISCUSSION}

Prescribing and using irrational antibiotic has reached a critical stage. Microbial resistance to antibiotics must be prevented. Rational use of antibiotics and discovery of nature products that have potential as antibacterial need to be encouraged to overcome the resistant problems (Vangalapati et al 2012, Nabavi et al 2015, Zhang et al 2015).

Cinnamomum burmannii ( $C$. burmannii) is an Indonesian native plant that has been widely used as a traditional medicine. It is known to have antimicrobial effects (Zhang et al 2015, Waty et al 2018), due to its component of cinnamaldehyde, that water soluble (Vangalapati et al 2012) and non-volatile component, including condensed tannins (proanthocyanidin and catechins), that less water soluble(Lekha and Lonsane, 1997). There are several theories for the antibacterial mechanism of $C$. burmannii. The active part of the extract component binds and penetrates the surface of microbial cells, through double phospholipid layer on the cytoplasmic membrane, and through membranebound enzymes. Therefore, this results barriers to its proton motive force, respiratory chain (creb's cycles) and ionic transfer, as well as becoming barriers to substrate oxidation. Furthermore, phosphorylation oxidative occurs, disruption to the active transport, reduced of metabolic products, and impaired synthesis of DNA, RNA, proteins, lipids and polysaccharides (Vangalapati et al 2012).

In this study, in vitro testing of the antibacterial and antifungi effect of $C$. burmanii water extraction was conducted. It shown in table 1 that from the bark of $C$. burmannii showed that it only had antibacterial against Staphylococcus aureus, MIC of $625-1,250 \mu \mathrm{g} / \mathrm{mL}$, and MBC of $1,250-2,500 \mu \mathrm{g} / \mathrm{mL}$. This result support data from previous study about $C$. burmanii against Staphylococcus aureus (Fadhlina et al 2013, Khakzadihe et al 2014, Zhang et al 2015, Waty et al 2018). C. burmanii is sensitive against bacteria gram positive growth.

Enterobacter spp., Pseudomonas aeruginosa, and Escherichia coli are bacteria gram negative that often use in $C$. burmanii studies. However, C. burmanii water extraction had no effects on inhibiting nor killing Enterobacter spp., Pseudomonas aeruginosa, and Candida albicans, even in the highest concentration of $10,000 \mu \mathrm{g} / \mathrm{mL}$, and this result against data that shown that the oil of $C$. burmanii has ability in inhibiting Candida albicans and Escherichia coli growth (Fadhlina et al 2013).

The main difference of bacteria gram positive and bacteria gram negative is in the constituent components of the cell. The wall of gram positive's cell has a skeleton that gives shape to bacteria, a thicker peptidoglycan layer, and richness of teicoic acid (Hett \& 
Rubin 2008, Hogg 2013). This structure allows cinnamaldehyde, the main component of $C$. burmanii that has antibacterial effect, entering into the cell (Vangalapati et al 2012). Bacteria gram negative's wall consists of outer membrane, thin peptidoglycan layer, and the periplasmic cavity. The outer membrane of bacteria gram negative consists double lipopolysaccharide layer and containing a lot of porin. The presence of a double lipopolysaccharide layer gives a negative charge to the surface of the bacteria, therefore lipophilic material is not allowed to enter (Groisman 2001, Rohilla 2010). Porin affects the bacterial escape mechanism against antibiotics or other antibacterial substances. Periplasmic cavity contains a layer of murein gel, which functions to capture nutrients from the environment, as well as enzymes for the degradation of macromolecules and detoxification of hazardous materials that successfully penetrate the outer membrane and peptidoglycan layer, such as antibiotics or substances with antimicrobial effects. Therefore, bacteria gram negative is more easily to be antibiotic resistant than bacteria gram positive (Rohilla 2010, Zhang et al 2015). The presence of gram negative outer membrane creates obstacles for antibacterial molecules to penetrate. Even if an antibiotic molecule is successful, the enzymes in the periplasmic cavity will damage the antibacterial before it reach its workplace.

Moreover, water extraction method may affect cinnamaldehyde, and condensed tannins (proanthocyanidin and catechins) production. Cinnamaldehyde is water solube however it is hard to enter the outer membrane of gram negative. The condensed tanins, that less water soluble, may less produce using water extraction method.

\section{CONCLUSION}

Cinnamomum burmannii water extraction has an antibacterial effect against Staphylococcus aureus with MIC of $625-1,250 \mu \mathrm{g} / \mathrm{mL}$ and MBC of 1,250-2,500 $\mu \mathrm{g} / \mathrm{mL}$. Therefore, $C$. burmanii with various ways of extraction has a potential effect for bacteria gram positive. However water extraction method was not suitable to enhance the $C$. burmanii antibacterial effect against Enterobacter spp., and Pseudomonas aeruginosa. Also has no effect against Candida albicans at the concentration of $10,000 \mu \mathrm{g} / \mathrm{mL}$.

\section{ACKNOWLEDGMENT}

This study was sponsored by Faculty of Medicine, Widya Mandala Catholic University Surabaya's research fund. Special thank to Ms. Martha Ervina,
M.Pharm. for supporting the Cinnamon burmanii water extraction.

\section{REFERENCES}

Aubert DF, Flannagan RS, Valvano MA (2008). A novel sensor kinase-response regulator hybrid controls biofilm formation and type VI secretion system activity in Burkholderia cenocepacia. Infection and immunity 76, 1979-91. doi: 10.1128/IAI.01338-07

Ervina M, Nawu YE, Esar SY (2016). Comparison of in vitro antioxidant activity of infusion, extract and fractions of Indonesian Cinnamon (Cinnamomum burmannii) bark. International Food Research Journal 23, 1346-1350

Fadhlina A, Binti I, Susanti D, Taher M (2013). Antimicrobial activity and synergic effect of Cinnamomum burmannii's essential oil \& its isolated compound (Cinnamaldehyde). International Conference on Chemical, Agricultural and Medical Sciences, 26-29. doi: http://dx.doi.org/10.15242/IICBE.C1213073

Ferry Y (2013). Prospek pengembangan kayu manis (Cinnamomum burmanii) di Indonesia. Sirinov 1, 1120

Forsythe SJ, Pitout J, Abbott SL (2015). Klebsiella, enterobacter, citrobacter, cronobacter, serratia, plesiomonas, and other enterobacteriaceae. In Manual of Clinical Microbiology. 11th Ed. American Society of Microbiology, 714-737. doi: 10.1128/9781555817381.ch38

Groisman E (2001) Principles of bacterial pathogenesis. Academic Press. Available at: http://books.google. com/books?hl=en\&lr=\&id=9wPz2ZdU430C\&oi=fnd $\& p g=P P 2 \& d q=$ Principles + of + Bacterial + Pathogenesis \&ots=JXE0iDiLB_\&sig=PxRDq-3WzTg9qxTdN28XX9cwcU. Accessed June 22014

Hett EC, Rubin EJ (2008). Bacterial growth and cell division: a mycobacterial perspective. Microbiology and molecular biology reviews: MMBR 72, 126-56. doi: 10.1128/MMBR.00028-07

Hogg S (2013) Essential microbiology. 2nd Ed. WileyBlackwell.

Khakzadihe M, Eslami H, Toupchi A, Houshmandpour P, Alizadeh M (2014). Study antibacterial effects of cinnamon extract on Staphylococcus aureus and Escherichia coli. International Journal of Biosciences (IJB) 5, 314-319. Available at: http://www.innspub. net/wp-content/uploads/2014/12/IJB-V5No12-p314319.pdf.

Lekha PK, Lonsane BK (1997). Production and application of tannin acyl hydrolase: State of the art. Advances in Applied Microbiology 44, 215-260. doi: 10.1016/S0065-2164(08)70463-5. 
Nabavi SF, Di Lorenzo A, Izadi M, Sobarzo-Sánchez E, Daglia M, Nabavi SM (2015). Antibacterial effects of cinnamon: From farm to food, cosmetic and pharmaceutical industries. Nutrients 7, 7729-7748. doi: 10.3390/nu7095359

Nester E, Roberts C, Pearsall N, McCarthy B (2013) Microbiology. 3rd Ed. Lippincott Williams and Wilkins. Available at: http://www.cabdirect.org/ abstracts/19782215075.html. Accessed June 2, 2014

Peterson JW (2017). Bacterial pathogenesis. doi: 10.1007/978-1-4939-6673-8

Public Health England (2014). UK Standards for Microbiology Investigations. Bacteriology 55, 1-21

Rohilla A (2010). Handbook of Bacteriology. Canadian Medical Association Journal. New Delhi, Oxford Book Company. Available at: http://www.ncbi.nlm. nih.gov/pmc/articles/PMC1708665/. Accessed October 82014

Ulbricht C, Bryan JK, Costa D, Culwell S, Giese N, Isaac R, Nummy K, Pham T, Rapp C, Rusie E, Weissner W, Windsor RC, Woods J, Zhou S (2015).
An evidence-based systematic review of Goji (Lycium spp.) by the natural standard research collaboration. Journal of Dietary Supplements 12, 184-240. doi: 10.1016/j.giec.2018.05.005

Vangalapati M, Sree Satya N, Surya Prakash DV, Avanigadda S (2012). A review on pharmacological activities and clinical effects of Cinnamon species. Research Journal of Pharmaceutical, Biological and Chemical Sciences 3, 653-663

Waty S, Suryanto D, Yurnaliza (2018). Antibacterial activity of cinnamon ethanol extract (Cinnamomum burmannii) and its application as a mouthwash to inhibit streptococcus growth. IOP Conference Series: Earth and Environmental Science 130. doi: 10.1088/ 1755-1315/130/1/012049.

Zhang Y, Liu X, Wang Y, Jiang P, Quek SY (2015). Antibacterial activity and mechanism of cinnamon essential oil against Escherichia coli and Staphylococcus aureus', Food Control. Elsevier Ltd 59 (January 2016), 282-289. doi: 10.1016/j.foodcont. 2015.05.032 